\title{
Solubility, Free Amino and Freeze-Thaw Stability of Soy Protein Isolated Prepared by Papain Modification
}

\author{
LIU Mu-jun, YU Guo-ping, Yao Yu-xiu, Guo Pei-pei, QI Wei-wei, Cai Xing-hang \\ College of food science \\ Northeast Agricultural University \\ Harbin, China \\ e-mail:1iumujun0@163.com,yuquopingneau@hotmail.com,1006333472@qq.com, \\ 986325454@qq.com, 770206120@qq.com, 654860046@qq.com
}

\begin{abstract}
Peptide size control is important for obtaining desirable functional properties so that these peptides can be better utilized. Proteolytic enzyme modification of soy protein isolates (SPI) is an effective way to fractionate these proteins into peptides with controlled molecular size. SPI was partial hydrolysis by papain at $\mathrm{pH} 7.0$ and $50^{\circ} \mathrm{C}$. Protein solubility, free amino groups, and freeze-thaw stability of the control SPI (without added papain) and hydrolysates were investigated. Hydrolysates that were prepared from SPI by papain modification had higher solubility, and better freeze-thaw stability. They could find use in products that require these properties.
\end{abstract}

Keywords-soy protein isolate; papain; freeze-thaw stability; protein solubility; free amino groups

\section{INTRODUCTION}

Soybean proteins are widely used in many foods as functional and nutritional ingredients. Soy protein based foods are now one of the fastest-growing categories in the food industry, resulting in the demand for manufacturing soy protein ingredients with improved processing characteristics. Soy protein isolate (SPI) is the most refined soy protein product, possessing many functional properties.

Many food emulsions are frozen to provide long-term stability of the product or as a necessary part of the food itself (e.g., ice cream) [1]. Nevertheless, most of $\mathrm{O} / \mathrm{W}$ emulsions are highly unstable when they are frozen and rapidly breakdown after thawing. When an $\mathrm{O} / \mathrm{W}$ emulsion is frozen, a variety of physicochemical processes can occur including fat crystallization, ice formation, freezeconcentration, interfacial phase transitions and biopolymer conformational changes [2].

Proteolytic enzyme modification of proteins is an effective way to improve their functionality. The peptides produced by partial proteolysis of proteins have smaller molecular size and less secondary structure than the original proteins. They contribute to increased solubility and significant changes in the foaming and emulsifying properties when compared with those of the original proteins [3]. To obtain desirable functional properties in soy protein hydrolysates, hydrolysis must be carried out under strictly controlled conditions to a generally low degree of hydrolysis. A limited degree of hydrolysis usually improves the emylsifying and foaming capacities, whereas excessive hydrolysis often causes loss of some of these functionalities.

To understand the basis of peptide functionality, it is essential to know the fundamental properties of the peptide, including protein solubility and free amino groups. Therefore, this study investigated these fundamental properties and the freeze-thaw stability of hydrolysates that were prepared by papain hydrolysis.

\section{Materials AND Methods}

\section{A. Materials}

Soy protein isolates (HAREBIN High Group Co.Ltd). Soybean oil (JIUSAN Oil Industry Group Co.Ltd). Papain (AOBOX Biotechnology Co.Ltd). Laboratory chemicals were of analytical grade, obtained from standard commercial sources, and used as received.

\section{B. Preparation of protein hydrolysates by papain}

Four $3 \mathrm{~g}$ portions of SPI were each dispersed in $100 \mathrm{~mL}$ deionized water, adjusted to $\mathrm{pH} 7.0$ and hydrolyzed with $7000 \mathrm{U} / \mathrm{g}$ of papain at $50^{\circ} \mathrm{C}$. The degree of hydrolysis was analyzed following the method of $\mathrm{pH}$-stat [4]. One dispersion was hydrolyzed for $1 \%$ degree of hydrolysis (DH1), the second dispersion was hydrolyzed for $2 \%$ degree of hydrolysis (DH2), the third dispersion was hydrolyzed for $3 \%$ degree of hydrolysis (DH3) , and the fourth dispersion was hydrolyzed for 4\% degree of hydrolysis (DH4) with constant shaking. The resulting hydrolysates were each heated at $100^{\circ} \mathrm{C}$ for $5 \mathrm{~min}$ to inactivate the enzyme.

\section{Protein solubility}

To determine protein solubility, SPI and hydrolysates solution were centrifuged at $4000 \mathrm{r} / \mathrm{min}$ for $20 \mathrm{~min}$. The nitrogen solubility index (NSI) was determined in accordance with the official GB/T 5009.52010 methods. Protein solubility was calculated as:

$$
\mathrm{NSI}(\%)=\mathrm{N}_{\text {sup }} / \mathrm{N}_{\text {total }} \times 100 \%
$$

Where $\mathrm{N}_{\text {sup }}$ was protein content in supernatant, and $\mathrm{N}_{\text {total }}$ was total protein content in sample. 


\section{Determination of free amino groups}

The levels of free amino groups of samples were determined by a modified OPA method. Glycine chosen as the standard reactant, formulated as $40 \mathrm{mmol} / \mathrm{L}$ standard solution, take $0,3,4,5,6,7,8,9,10 \mathrm{uL}$, and corresponding with deionized water up to $10 \mathrm{uL}$, add $3 \mathrm{~mL}$ OPA reagent, then the mixture was incubated for $2 \mathrm{~min}$ at room temperature, with deionized water as blank control was conducted in the $340 \mathrm{~nm}$ and drawing standard curve. The standard curve of free amino is shown in Figure 1. SPI and hydrolysates solution $(10 \mathrm{uL})$ and OPA reagent $(3 \mathrm{~mL})$ were blending for $2 \mathrm{~min}$. The absorbance at $340 \mathrm{~nm}$ was measured by UV spectrophotometer.

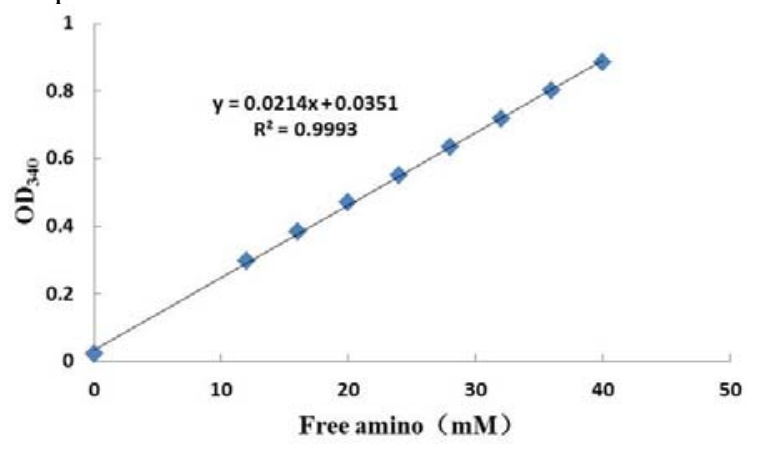

Figure 1. Standard curve of free amino.

\section{E. Preparation of model oil-in-water emulsions}

Oil-in-water emulsions were prepared by mixing soy oil (oil volume fraction, $\Phi=0.2$ ) with $1.6 \% \mathrm{w} / \mathrm{v}$ protein dispersions in a high-speed blender at 20,000 rpm for $60 \mathrm{~s}$.

\section{F. Freeze-thaw protocol}

Freeze-thaw treatments of o/w emulsions were performed immediately their preparation. Samples $(20 \mathrm{ml})$ were transferred to thin-walled glass tubes and were isothermally stored in still air for $24 \mathrm{~h}$ at $-20^{\circ} \mathrm{C}$. After storage, frozen samples were thawed into a water bath at $40^{\circ} \mathrm{C}$ for $2 \mathrm{~h}$, and stored at $25^{\circ} \mathrm{C}$ before further characterization analyses.

\section{G. Determination of droplet size and distribution}

The emulsion droplet size and its distribution were determined by laser scattering using a Micro Particle Analyzer. The $\mathrm{d}_{3,2}$ expressed as emulsion particle size.

\section{H. Determination of free fat}

The degree of emulsion destabilization was measured by the amount of free oil after freeze-thaw by the method of Palanuwech [5]Erreur : source de la référence non trouvée5. In this work, In order to determinate the amount of free oil, 4 $\mathrm{g}$ of dye solution was gently mixed with $16 \mathrm{~g}$ of emulsion sample, incubated for $60 \mathrm{~min}$ and then centrifuged at $1000 \mathrm{~g}$ for $20 \mathrm{~min}$. An aliquot of dyed free oil on top of emulsion $(1.5 \mathrm{ml})$ was carefully sucked off with a Pasteur pipette and centrifuged at $15000 \mathrm{~g}$ for $20 \mathrm{~min}$. The absorbance of supernatant at $508 \mathrm{~nm}$ was then determined. The change in the absorbance due to dye dilution was related to the oiling off, according to the following expression:

$$
\text { Oiling off }=\left[\mathrm{M}_{0} \times(\mathrm{a}-1) /\left(\mathrm{M}_{\mathrm{e}} \times \Phi_{\mathrm{d}}\right)\right] \times 100 \%
$$

Where $M_{0}$ is the mass of added dye solution, $M_{e}$ is the mass of emulsion, $\Phi_{\mathrm{d}}$ is the mass fraction of oil in the emulsion and $\mathrm{a}$ is the ratio of the measured absorbances of the dye before $\left(A_{1}\right)$ and after $\left(A_{2}\right)$ extraction process.

\section{Creaming index}

The prepared emulsion (10 g) was transferred into a test tube that was tightly sealed with aplastic cap. After freezethaw cycle, emulsions separated into a number of layers with different visual appearances. The thickness of each of the layers formed was determined visually using a ruler. The extent of creaming was characterized by creaming indices, which were defined as:

$$
\mathrm{CI}(\%)=\mathrm{HSL} / \mathrm{HT} \times 100 \%
$$

Where HSL was the height of the serum layer, and HT was the total height of the emulsions.

\section{J. Statistical analysis}

The experiment was replicated twice with at least triplicate analyses. Data were analyzed by using the General Linear Models procedure of Statistic 8.1 software package (Analytical Software, St. Paul, MN) for microcomputer. Analysis of variance (ANOVA) was done to determine the significance of the main effects. Significant differences $(\mathrm{P}<$ 0.05 ) among means were identified using Turkey procedures.

\section{Results AND Discussion}

\section{A. Protein solubility}

Solubility characteristics of protein are among the most important functional properties since many functional performances of proteins depend upon their capacity to go into solution initially [6]. The solubility of SPI and hydrolysates are shown in Table I. Papain modification greatly improved the protein solubility. After hydrolysis, NSI from $19.59 \%$ for control SPI to $21.17 \%, 30.1 \%, 44.94 \%$ and $48.35 \%$ for DH1, DH2, DH3 and DH4, respectively.

TABlE I. The Solubility of SPI AND Hydrolysates

\begin{tabular}{ll}
\hline \multicolumn{1}{c}{ Samples } & \multicolumn{1}{c}{ NSI (\%) } \\
\hline SPI & $19.59 \pm 0.58 \mathrm{a}$ \\
DH1 & $21.17 \pm 1.11 \mathrm{a}$ \\
DH2 & $30.10 \pm 0.44 \mathrm{~b}$ \\
DH3 & $44.94 \pm 0.75 \mathrm{c}$ \\
DH4 & $48.35 \pm 0.57 \mathrm{~d}$ \\
\hline
\end{tabular}

SPI with the lowest NSI, probably due to formation of protein aggregates that buried hydrophobic sites. In addition, papain hydrolysis could lead to unfolding of protein molecules. Not only nonpolar amino acid groups but also some polar amino acid groups, buried inside protein molecules, could be exposed on the surface of protein molecules after unfolding. These exposed polar amino acids may interact with water molecules through hydrogen bonds 
and electrostatic interactions, resulting in increased protein solubility.

\section{B. Free amino groups}

TABLE II. The Free Amino Groups of SPI and Hydrolysates

\begin{tabular}{ll}
\hline \multicolumn{1}{c}{ Samples } & \multicolumn{1}{c}{ Free amino groups $(\mathbf{m M})$} \\
\hline SPI & $8.25 \pm 0.24 \mathrm{a}$ \\
DH1 & $12.90 \pm 0.07 \mathrm{~b}$ \\
DH2 & $14.93 \pm 0.12 \mathrm{c}$ \\
DH3 & $16.92 \pm 0.10 \mathrm{~d}$ \\
DH4 & $17.93 \pm 0.13 \mathrm{e}$ \\
\hline
\end{tabular}

As shown in Table II, you can see that as the hydrolysis reaction of soybean protein isolated, protein continuously produce free amino. After hydrolysis, free amino groups from $8.25 \mathrm{mM}$ for control SPI to $12.9 \mathrm{mM}, 14.93 \mathrm{mM}$, $16.92 \mathrm{mM}$ and $17.93 \mathrm{mM}$ for $\mathrm{DH} 1, \mathrm{DH} 2, \mathrm{DH} 3$ and $\mathrm{DH} 4$, respectively. Changes in free amino groups indicate modified protein conformation.

Number of free amino groups content to a certain reflects the strength of the hydrophilic [7], the increase of the free amino leads to the reducing of the solution surface hydrophobicity, and influenced the stability of the hydrolysate emulsion.

\section{Effect of limited hydrolysis treatment on the freeze- thaw stability of o/w emulsions}

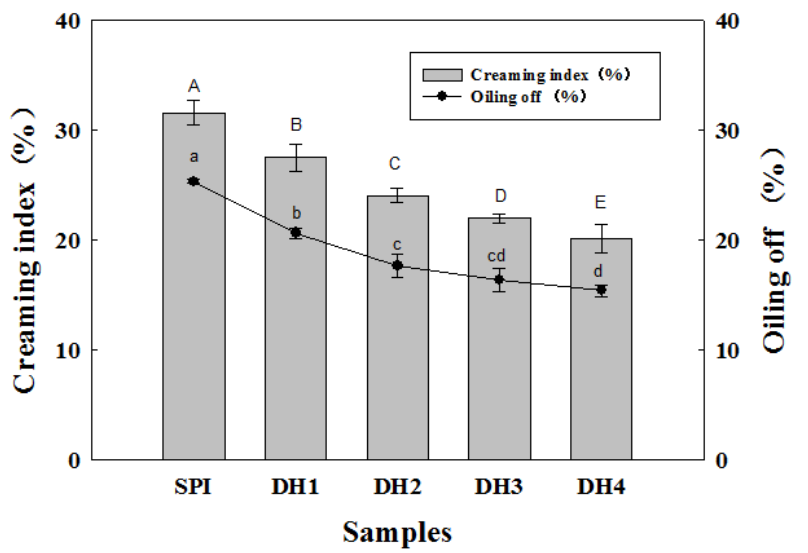

Figure 2. Creaming index and oiling off of SPI and hydrolysates emulsion after freezing-thawing.

Figure 2 shows the creaming index and oiling off of SPI and hydrolysates emulsion after freezing-thawing. It was found that limited hydrolysis largely improve the stability of the emulsion. For the unhydrolyzed controls, the creaming index and oiling off of the SPI was higher than those of hydrolysates. With the increase of degree of hydrolysis, freeze-thaw emulsion stratification coefficient and oiling off is on the decline, when the degree of hydrolysis was $4 \%$, the emulsion stratification coefficient and oil off was lowest, the emulsion showed good freeze-thaw stability.

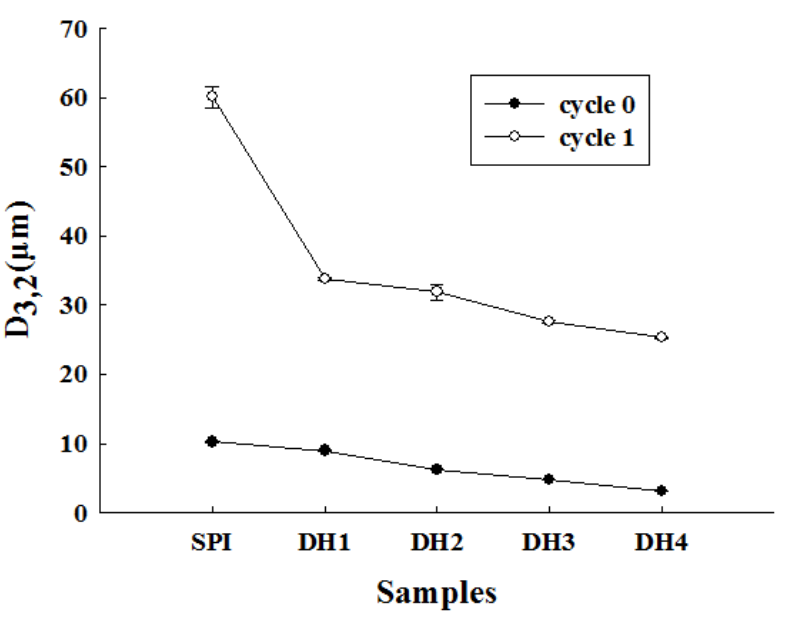

Figure 3. The $\mathrm{D}_{3,2}$ of SPI and hydrolysates emulsion before and after freezing - thawing.

Figure 3 shows the $\mathrm{D}_{3,2}$ of SPI and hydrolysates emulsion before and after freezing-thawing. SPI relative terms, in the fresh preparation of emulsion, since better emulsifying properties of hydrolysates, and the ability to form relatively thick interfacial films on the surface of oil droplets, prevent aggregation between the droplets, thus promoting the formation of micro emulsion particles, the emulsion system more stable. The emulsion is freeze-thaw process, SPI's $D_{3,2}$ were increased significantly. In the hydrolysates as emulsifier to the emulsion, which has a smaller amplitude $\mathrm{D}_{3,2}$ increased, this shows that in hydrolysate of emulsion had good freeze-thaw stability.

\section{Conclusions}

In this experiment, soybean protein isolated as raw material, which was limited hydrolysis by papain. Hydrolysates were made of $\mathrm{O} / \mathrm{W}$ emulsion by the high pressure homogeneous, the effect of papain limited hydrolysis on protein solubility, free amino groups and the freeze-thaw stability. The freeze-thaw stability was characterized by measurements of creaming index and oiling off after isothermal storage at $-20^{\circ} \mathrm{C}$ for $24 \mathrm{~h}$ and further thawing. The experimental results showed that the modified soybean protein isolated by papain, whose freeze-thaw stability significantly $(\mathrm{P}<0.05)$ higher than the unmodified protein, the freeze-thaw stability of DH4 samples improve the most significant.

\section{ACKNOWLEDGMENT}

This study was supported by Natural Science Foundation of China (Grant no. 31071493).

\section{REFERENCES}

[1] S. Ghosh, and J.N. Coupland, "Factors affecting the freeze-thaw stability of emulsions," Food Hydrocolloids, 2008, vol. 22, pp. 105111 ,

[2] D.J. McClements, "Protein-stabilized emulsions," Current Opinion in Colloid and Interface Science, 2004, vol. 9, pp. 305-313. 
[3] J.Z. Wu, M.M. Zhao, and Z.X. Ning, "Study on papain hydrolysate for soy protein isolate," soybean Science, 2002,vol. 3(21), pp. 187190.

[4] Y.C. Xu, and C.H. Liu, "Introduction of method for determination of degree of hydrolysisof protein hydrolysates," Food Research and Development, 2007, vol. 28(7), pp. 173-176.

[5] J. Palanuwech, R. Potineni, and R.F. Roberts, "A method to determine free fat in emulsions," Food Hydrocolloids, 2003, vol. 17(1), pp. 55-62.
[6] Y.K. Sook, S.W. Park, and K.C. Rhee, "Functional Properties of Proteolytic Enzyme Modified Soy Protein," American Chemical Society, 1990,vol. 38, pp. 651-656

[7] J. Liu, "Enhancing the foaming and emulsifying properties of soybean protein isolate by enzymatic modification," WuXi: Jiangnan University, 2008 